\title{
Climatic and environmental events over the Last Termination, as recorded in The Netherlands: a review
}

\author{
W.Z. Hoek ${ }^{1} \&$ S.J.P. Bohncke ${ }^{2}$ \\ The Netherlands Centre for Geo-ecological Research (ICG) \\ 1 Department of Physical Geography, Faculty of Geographical Sciences, Universiteit \\ Utrecht, Heidelberglaan 2, NL-3508 TC Utrecht, The Netherlands; \\ e-mail:W.Hoek@geog.uu.nl \\ ${ }^{2}$ Department of Quaternary Geology and Geomorphology, Faculty of Earth and \\ Life Sciences, Vrije Universiteit Amsterdam, De Boelelaan 1085, NL-1081 HV \\ Amsterdam, The Netherlands.
}

Manuscript received: May 2001; accepted: December 2001

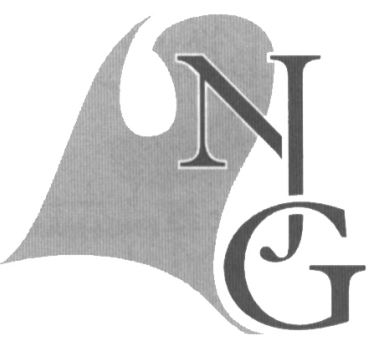

\begin{abstract}
The Last Termination, or Weichselian Lateglacial (ca 15-10 ka cal. BP), is a time period with rapid changes in climate and environment. The oxygen-isotope records of the Greenland ice-cores are regarded as the most complete climate proxy for the North Atlantic region. In The Netherlands several other proxies have been investigated and dated in great detail over the last few decades. However, changes registered in the different records are not by definition causally related to climate changes. Comparison of the different records on a common time-scale permits evaluation of the interrelationships and correlations to the Greenland ice-cores. Some events are the result of the complex interplay of different environmental variables and have no causal relationship with climate changes at all. By comparing the different records on a common time-scale and examining spatial patterns, the links between the proxies become evident.
\end{abstract}

Key words: Lateglacial, palaeoclimate, geomorphology, vegetation, The Netherlands

\section{Introduction}

The Last Termination (Weichselian Lateglacial) forms the transition from the cold Pleniglacial to the warm Holocene. The changes in climate are classically studied by palynological investigations. However, changes in climate influenced the whole landscape. Not only vegetation responded to these changes, which is shown by the large number of palaeo-ecological studies, but also the abiotic landscape reacted to climate change due to changes in hydrology, erosion, sedimentation and soil development (Hoek, $1997 a, b)$. These changes in the abiotic landscape influenced vegetation development and patterns (Hoek, 2000 ) but, on the other hand, vegetation also affected the abiotic landscape by influencing e.g. sedimentation, erosion and soil formation.

A great number of palynological data considering the Lateglacial have been collected in NW-Europe and especially The Netherlands during the last decades. Therefore, the general vegetation development for this period is well known, and we can use the vegetation record as a means for correlation (Hoek, 1997c). Furthermore, the vegetation development can be linked to the changes in the geomorphology that have also been investigated in great detail in The Netherlands. Fig. 1 gives a reconstruction of the main landscape types in The Netherlands for the period under investigation.

In this paper, different environmental phenomena in the Lateglacial landscape of The Netherlands are presented. These forms and processes are often related to climate, but we will show that complex interrelationships exist. Amongst others, the interactions between vegetation and geomorphological processes are discussed. For comparison with other records, age estimates in this paper are given both as reported radiocarbon ages $\left({ }^{14} \mathrm{C} \mathrm{BP}\right)$ for local phenomena and 


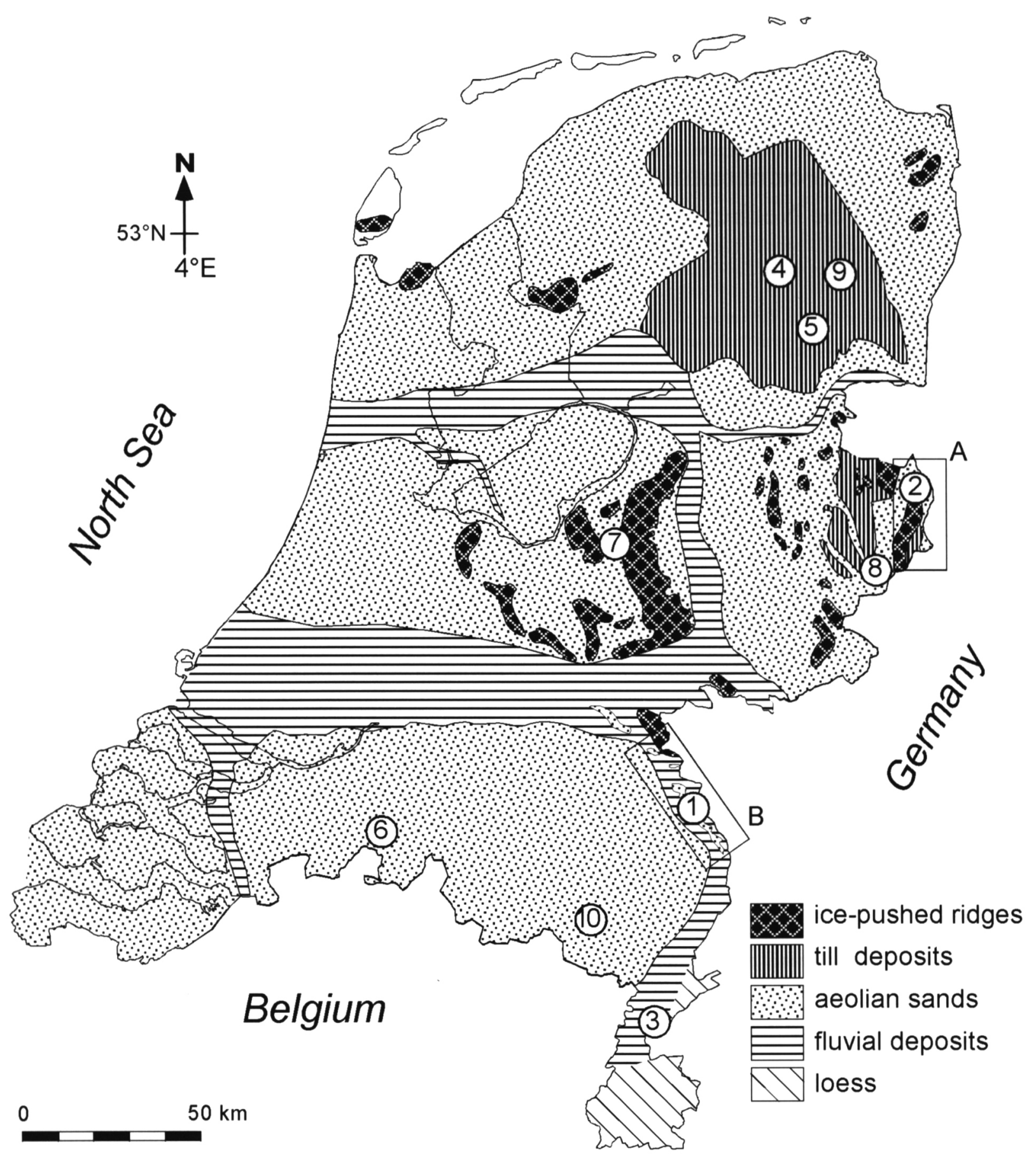

Fig. 1. Reconstruction of the landscape in The Netherlands during the Weichselian Lateglacial (after Hoek, 2000), with locations mentioned in the text: 1: Bosscherheide, 2: De Borchert, 3: Gulickshof, 4: Hijkermeer, 5: Mekelermeer, 6: Notsel, 7: Uddelermeer \& Bleekemeer, 8: Usselo, 9: Uteringsveen, 10:Weerterbos, A: Dinkel Valley, B: Meuse Valley.

INTCAL98 calibrated ages (Stuiver et al., 1998) for the main events (ka cal. BP). The events are compared to the classical chronostratigraphic subdivision (Mangerud et al., 1974) as well as the INTIMATE Greenland Icecore Stratigraphy (Björck et al., 1998). For the comparison with the Greenland isotope record we used GISP2 (Stuiver et al., 1995) because the GISP2 timescale in ice-years correlates better to the INTCAL98 calibrated timescale (see also Lowe et al., 2001).

\section{Perspective}

Deposits ascribed to the Weichselian Lateglacial period in The Netherlands have already been analysed palynologically by Florschütz in 1939, but the first proper lacustrine pollen record from Hijkermeer was compiled by Van der Hammen in 1949 (Fig. 2). His arguments for a Lateglacial age of the lake sediments, beside its stratigraphical position, were based on parallels in the vegetational development with the 


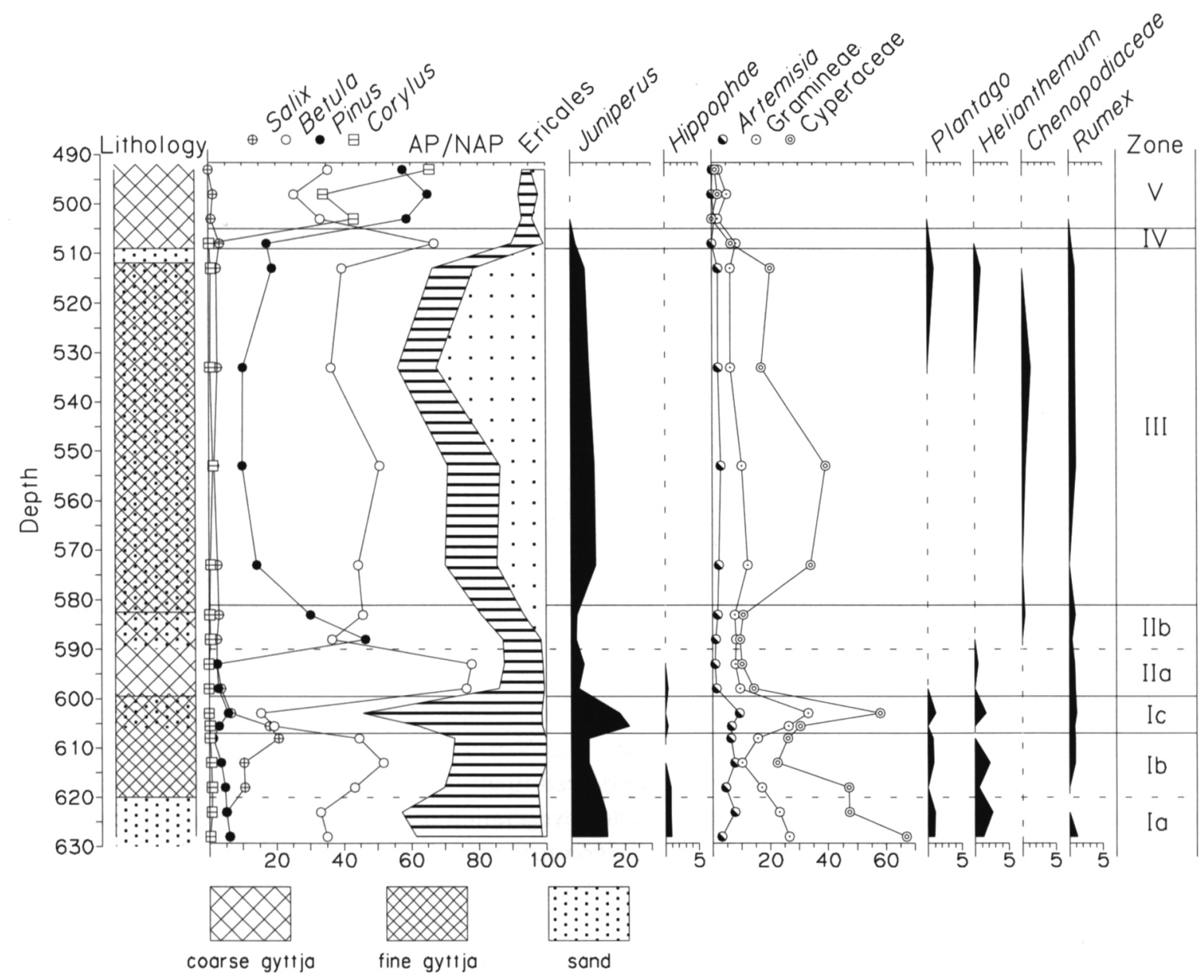

Fig. 2 Interstadial Bølling (Ib) and Allerød (II) oscillations in pollen diagram Hijkermeer (modified afterVan der Hammen, 1949).

records produced by Iversen (1947) in Denmark. The Allerød period pre-eminently was characterised as a period of landscape stability, during which little clastic material was supplied to the lake leading to the deposition of a pure detrital gyttja. Beside the Allerød interstadial (II) also the Bølling interstadial (Ib) was proved to be present in the lake sediments (Fig. 2). Both interstadials were separated by a supposedly cold stadial called the Earlier Dryas (Ic). Implications with respect to the Lateglacial climate were drawn and a refined subdivision of the Lateglacial was proposed following the one that Iversen (1947) developed. Gradually a picture of the Lateglacial vegetation development in relation to climate and landscape development emerged (Van der Hammen, 1951). This idea was refined with the investigations of Van der Hammen \& Wijmstra (1971) in the Dinkel valley. This study provided a comprehensive picture of the aeolian lithostratigraphy and vegetational development over the period involved (Fig. 3).

With the research at Usselo (Van Geel et al., 1989) and De Borchert (Van Geel et al., 1981) two detailed radiocarbon-dated standard profiles for the Late- glacial and Early Holocene vegetation development in The Netherlands became available (Fig. 4).

Regional differences in Lateglacial vegetation development (Bohncke, 1993) and the occurrence of lake-level fluctuations (Bohncke \& Wijmstra, 1988) revealed the close interaction between vegetation change and abiotic factors other than temperature. The role of the rivers during this specific time-interval drew much attention and clarified many of the geomorphological processes that took place (e.g. Vandenberghe et al., 1987; Bohncke et al., 1993; Berendsen et al., 1995; Kasse et al., 1995; Huisink, 1999). A critical review of available radiocarbon dates from over 100 pollen diagrams has led to a chronological framework for the general Lateglacial and Early Holocene vegetation development in The Netherlands and direct surroundings (Hoek, 1997c). This chronological framework made it possible to compare vegetation development with other proxy records (Hoek, 1997a,b). The Lateglacial calcareous gyttja deposits at Gulickshof (Hoek et al., 1999) gave the opportunity to study Lateglacial environmental changes with different methods e.g., pollen, plant 


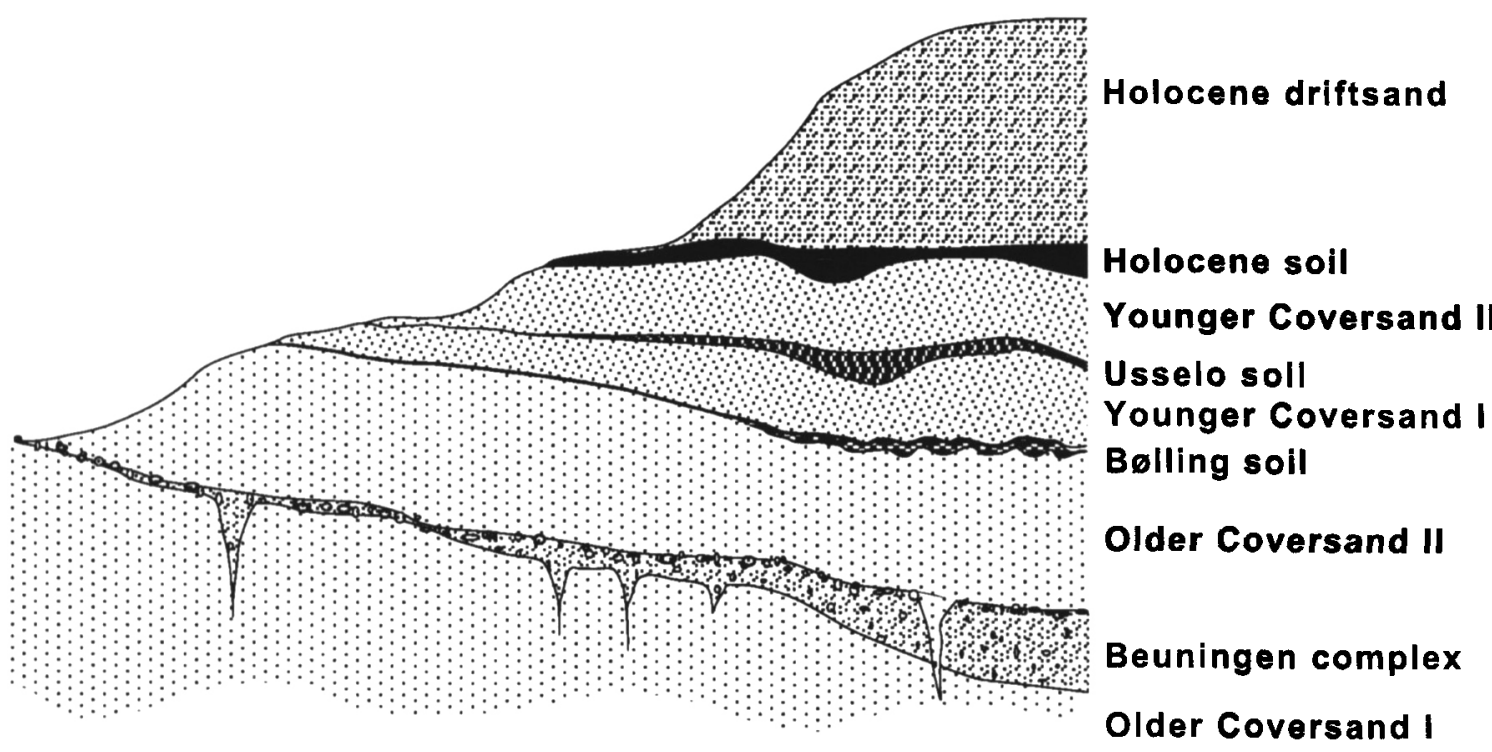

Fig. 3. Schematic lithological cross-section of the profiles exposed along the Dinkel river in Twente (eastern Netherlands), on which the aeolian Lateglacial lithostratigraphy for The Netherlands is based (modified after Wijmstra \& Schreve-Brinkman, 1971). Also depicted is the presence of thermal contraction cracks in the deposits below the Belling soil.

macro-fossils, fresh water mollusca, stable isotopes and geo-chemical analyses. The evidence was fitted into the Lateglacial chronostratigraphy with the help of biostratigraphic correlation and AMS-dates on terrestrial plant macro-fossils. One of the most recent findings is that the stable isotope record from specific calcareous lake deposits may be correlated to the Greenland ice-core records in detail (Hoek \& Bohncke, 2001).

\section{Lateglacial climate}

Changes in climate occurred very quickly during the Last Termination. At the start of the Lateglacial round $14.8 \mathrm{ka}$ cal. BP mean July-temperature rose by $3-5^{\circ} \mathrm{C}$ and marked changes in precipitation also seem to have occurred (Renssen \& Isarin, 2001). It is not a surprise that this abrupt shift in climatic conditions had a far-reaching effect on vegetation and geomorphological processes.

\section{Climate proxies}

As described above, palynological changes form the basis for the subdivision of the Late Weichselian to Early Holocene transition. Although the vegetational record gives a qualitative estimate for climate change, a precise reconstruction of the climatic signal based on pollen assemblages cannot be achieved (Van Geel, 1996; Hoek, 2001). For instance, based on the AP (Arboreal Pollen) percentage it was concluded that the warmest part during the Lateglacial fell within the Allerød interstadial, just before the Younger Dryas sta- dial (e.g. Van der Hammen, 1951; Iversen, 1973). It appeared that this classical interpretation of Lateglacial vegetation and climate development leads to a different picture than the records obtained from, for instance, the Greenland ice-cores (Johnsen et al., 1992; Grootes et al., 1993) and Coleoptera studies (Atkinson et al., 1987; Coope et al., 1998). Both, oxygen-isotopes and fossil Coleoptera, are regarded to reflect changes in temperature almost instantaneously. This implies that the warmest phase must have occurred early in the Lateglacial, where temperature reconstructions based on isotopes and Coleoptera reach their highest values. Contrarily to what was assumed earlier, the Pinus increase around $13.2 \mathrm{ka} \mathrm{cal}$. BP does not represent the Lateglacial climatic optimum but instead seems a reaction to increased continentality in the climate (Bohncke, 1993). New investigations suggest that this vegetational change can be correlated to the colder GI-1b event (Hoek et al., 1999).

Quantitative palaeoclimatic indicators such as Coleoptera have rarely been investigated in The Netherlands; in Usselo I (Van Geel et al., 1989) and Notsel (Bohncke et al., 1987) palaeotemperature records were constructed based on fossil Coleoptera in combination with botanical evidence. Additionally, botanical climate indicator species appeared to be a useful method to reconstruct palaeo-temperatures quantitatively (Iversen, 1954; Kolstrup, 1980; Zagwijn, 1994; Isarin \& Bohncke, 1999). Using the indicator species method, summer temperature reconstructions can best be made on the presence of aquatic species. A recent development is the use of oxygen isotope analysis measured on lacustrine carbonates, 
which at Gulickshof and Weerterbos resulted in signals that can be compared in detail to the Greenland oxygen isotope records (Hoek \& Bohncke, 2001).

The combination of different, both quantitative and qualitative palaeoclimate indicators, such as Coleoptera, botany and geomorphology can give supplemental information about climate change. For instance, the combination of Coleoptera and periglacial structures gives information about summer and mean annual temperatures, from which winter temperatures can be deduced (Isarin et al., 1998).

Compared to temperature, it is far more difficult to reconstruct precipitation changes. Nevertheless, combination of evidence can be used to deduct changes in precipitation. Lake level fluctuations and changes in fluvial and aeolian activity give information about the qualitative changes in precipitation (Huijzer $\&$ Isarin, 1997). Lake-level curves from Mekelermeer, Bleekemeer and Uddelermeer show clear lake-level changes during the Lateglacial (Bohncke \& Wijmstra, 1988). Lake-level change in the sense of decreasing water depth as a result of hydroseral succession can be explained as a natural process. The opposite process e.g. the return to open water conditions (increased water depth) can be regarded as a response to augmented effective precipitation. In the palynological record, indicator species that are sustainable for drought reacted to changes in humidity, especially in the welldrained environments. This is particularly the case for most aquatic taxa and more terrestrial taxa such as Betula, Cruciferae, Potentilla palustris and Selaginella selaginoides. Other taxa were favoured by increasing drought; Pinus, funiperus, Artemisia, Helianthemum and Ephedra distachya preferably grew at dry, well drained locations.

\section{Lateglacial temperature}

In the beginning of the Lateglacial round $14.8 \mathrm{ka}$ cal. BP (GI-1e) the basins in the landscape appear to have a low nutrient status except for the presence of calcium and therefore seem to lack critical indicator species, which happen to prefer more nutrient rich conditions. In the absence of sensible plant indicator species, temperature reconstructions for the Bølling are solely based on fossil Coleoptera faunas. At Usselo, Van Geel et al. (1989) reconstructed mean summer temperatures between 15 and $20^{\circ} \mathrm{C}$.

From 14.1 ka cal. BP (GI-1d), mean July-temperatures dropped from between 15 and $20^{\circ} \mathrm{C}$ to between 15 and $16^{\circ} \mathrm{C}$ (Bohncke et al., 1987; Van Geel et al., 1989). Previously, in the absence of Coleoptera analyses that could provide evidence about mean temperatures of the warmest month, estimates of summer temperatures were based on fluctuations in tree species, especially birch. A decline in birch was at first thought to be an indication of a decline in mean July temperatures to below $10^{\circ} \mathrm{C}$ during this phase. The introduction of Coleoptera data for summer temperature reconstructions did not suggest such a dramatic decline. It appears that the recorded decline in Betula can be attributed to other factors than temperature (see below). Since there is an absence of periglacial structures other than frost cracks (Van Geel et al., 1989) that can be assigned to this period, mean January-temperatures may well have declined but would not have been lower than $-15^{\circ} \mathrm{C}$.

From $14.0 \mathrm{ka}$ cal. BP (GI-1c), the presence of Typha angustifolia, Nymphaea alba and Nuphar lutea facilitate the reconstruction of a mean July-temperature of at least $14^{\circ} \mathrm{C}$, while Coleoptera assemblages provided a temperature range of between 13 and $16^{\circ} \mathrm{C}$. Mean January-temperatures are estimated in the range between -16 and $+6^{\circ} \mathrm{C}$. At the end of the Allerød round 13,2 ka cal. BP (GI-1b), there seems evidence for a further decline in mean July-temperatures. Januarytemperatures for this time interval are considered to have declined to between -13 and $-16^{\circ} \mathrm{C}$, the lower limit of the mean January-temperature range inferred from Coleoptera data for The Netherlands. With summer temperatures almost unchanged these temperature conditions would allow for deep seasonal frost and a more intensive action of the freeze-thaw cycle. This is supported by the disappearance of molluscs at Gulickshof, presumably the result of repetitive and long lasting freezing (Hoek et al., 1999).

At the transition of the Late Allerød (GI-1a) to the Younger Dryas (GS-1) round $13.0 \mathrm{ka}$ cal. BP a major and abrupt change in the climate occurred. Based on Coleoptera evidence, mean July-temperatures fell from between 15 and $18^{\circ} \mathrm{C}$ to between 10 and $11^{\circ} \mathrm{C}$ while mean January-temperatures ranged from between -16 and $+6^{\circ} \mathrm{C}$ to between -15 and $-7^{\circ} \mathrm{C}$ (Bohncke et al., 1987). Based on botanical evidence mean July-temperatures were between 11 and $13^{\circ} \mathrm{C}$ (Isarin \& Bohncke, 1999). Hence, mean annual temperatures declined to below $-1^{\circ} \mathrm{C}$, probably between -2 and $-5^{\circ} \mathrm{C}$, and allowed for the development of discontinuous permafrost, which is supported by fossil periglacial phenomena (Isarin, 1997).

This period came to an end when round $12.7 \mathrm{ka}$. cal. BP, the mean annual temperature rose to above $-1{ }^{\circ} \mathrm{C}$ and discontinuous permafrost conditions were terminated. Periglacial structures can only be found in the lower part of the Younger Dryas sediments (Isarin, 1997). Mean July-temperatures rose to values between 13 and $15^{\circ} \mathrm{C}$ (Isarin \& Bohncke, 1999). In the absence of a protecting snow cover, conditions 
may still have been very severe for plant-life.

The beginning of the Holocene is biostratigraphically marked by a distinct increase in Betula preceded by a funiperus maximum (see Fig. 4). Mean July-temperatures are likely to have restored to the Lateglacial interstadial values $\left(15\right.$ to $\left.17^{\circ} \mathrm{C}\right)$. An assessment of the mean January-temperatures is more difficult to give. Taking into account the configuration of North West Europe with the sea-level being still low, one would expect a rather continental climate. Van Geel et al. (1981) demonstrated that the registered changes during the Preboreal (round $11.2 \mathrm{ka}$ cal. BP) could not only be ascribed to a decline in winter temperatures but that to some extent a palaeohydrological aspect played a role (see below).

\section{Lateglacial wetness}

Based on the wide-spread occurrence of coversand deposits and the absence of organics from the period preceding the Lateglacial, we can deduce that climatic conditions were extremely cold and dry and vegetation was almost absent in the period preceding the Lateglacial. Sedimentary structures that indicate running water are rare. It is believed that there was a general shortage in effective precipitation and this may well have been a limiting factor for the spreading of shrubs and trees.

Based on changes in lake-levels, wetness can be reconstructed for the period under investigation (see Fig. 5). Round $14.8 \mathrm{ka}$ cal. BP (GI-1e) shallow lacustrine conditions start, mainly as the result of the melting of ground ice. Subsequently lake-levels seem to have increased and lake-level remained high during the Bølling (GI-1e) (Bohncke \& Wijmstra, 1988; Hoek et al., 1999).

Between 14.1 and $14.0 \mathrm{ka}$ cal. BP (GI-1d) a temporary low in the lake-levels is recorded by an increased representation of species from the fringe zone of the lake (Bohncke \& Wijmstra, 1988). This temporary low in the lake levels during this period (GI-1d) can be ascribed to drought and consequently by a decline in precipitation, which was earlier suggested by Van Geel \& Kolstrup (1978) as the explanation for the regional birch decline. This indication of drought is supported by the widespread occurrence of aeolian deposits from this period (see below).

Early in the Allerød period from $14.0 \mathrm{ka}$ cal BP onward (GI-1c), palaeohydrological studies reveal the return to high lake-levels (Bohncke \& Wijmstra, 1988) and increased fluvial discharges (Bohncke \& Vandenberghe, 1991). The spread of wet localities in the landscape enabled birch to regain its position in the regional vegetation. It cannot be excluded that the palaeohy- drological changes can partly be attributed to increased effective precipitation or a significant winter snow cover. This period was dominated by high lake levels except during a short phase round $13.5 \mathrm{ka}$ cal. BP. Furthermore, during the Pinus-phase of the Allerød at around 13,2 ka cal. BP (GI-1b) the lacustrine basins reach another low in the lake-levels, sometimes leading to hiatuses in the sedimentary sequence, this event culminates shortly before $13.0 \mathrm{ka} \mathrm{cal}$. BP (GI-1a).

At $13.0 \mathrm{ka}$ cal. BP, the transition towards the Younger Dryas (GS-1) a sudden rise in lake-level simultaneous with increased erosion in the surroundings of the lakes was recorded. This wet period coincides with a drop in temperature indicated by periglacial structures. These periglacial structures occurred partly because the sediments were presumably humid enough for segregation ice to develop. Lakelevels dropped round $12.7 \mathrm{ka}$ cal. BP when species growing in the border zone of the lake start to increase. Especially mosses that thrive in shallow water appear in the sequences. Recorded increase in aeolian activity also points to dryer conditions. Dry soil conditions re-established probably caused by a decline in the precipitation. Furthermore, the disappearance of ground ice due to temperature rise, might have enlarged this drought as water could now freely percolate into the subsoil.

At the start of the Holocene (11.8 ka cal. BP) a return to higher lake-levels is recorded, deduced from the increase in aquatic taxa simultaneously with a decline in telmatic taxa. Also, the spread of both Betula pubescens and Filipendula argue for a spread of wet localities. The spread of wet localities only occurs locally where due to favourable conditions accumulation of organic sediment takes place. In other localities the early Holocene is represented by a hiatus. In lake records, this episode of increasing water depth is interrupted by a short lasting phase (11.3-11.2 ka cal. BP) with shallow water conditions whereby mosses penetrated the open water. Together with other telmatic species a hydroseral succession seem to have set in. Biostratigraphically this occurs during the Rammelbeek-phase of the Preboreal. The subsequent increase in aquatic taxa marks a rise in the lake-levels and the termination of the previous dry interval.

\section{Lateglacial vegetation development}

The Lateglacial and Early Holocene vegetation development is presented in detail by Hoek (1997c, 2001), therefore we present only a summary below, the main features of the vegetation development and sub-division in Pollen Assemblage Zones (PAZ) can be recognised in Fig. 4. 


\section{De Borchert}

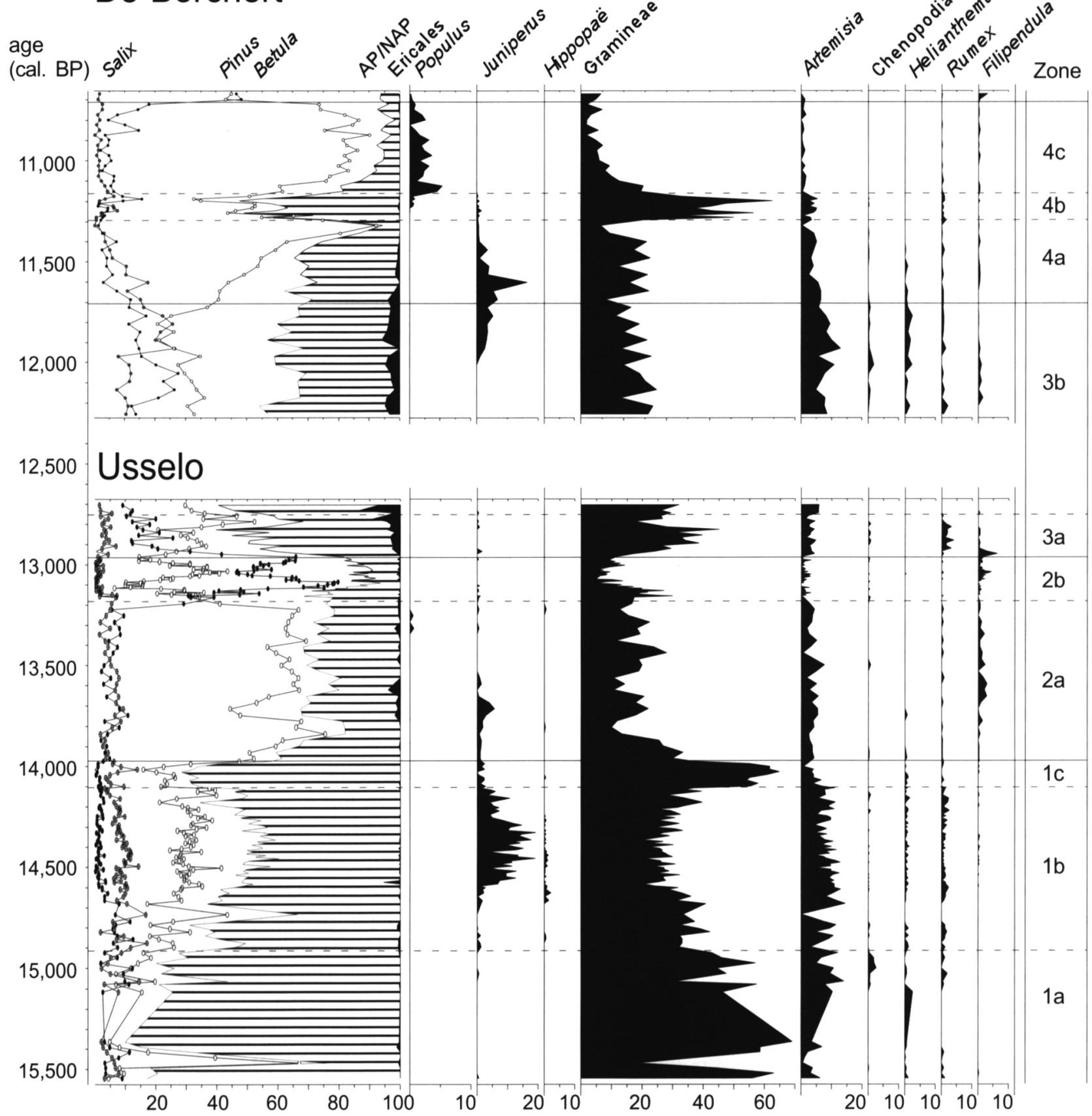

Fig. 4. Compilation of two pollendiagrams from Twente (eastern Netherlands), a selection of taxa and the lithology are presented plotted against the INTCAL98 calibrated 14C timescale. A: De Borchert (after Van Geel et al., 1981) B: Usselo I (after Van Geel et al., 1989). P = peat (black), $S=$ sand (light grey), $P / S=$ sandy peat/peaty sand (dark grey).

Before $15.5 \mathrm{ka}$ cal. BP $\left(12,900{ }^{14} \mathrm{C} \mathrm{BP}\right)$ there was a sparse vegetation cover comprising Gramineae, $\mathrm{Cy}$ peraceae, Saxifragaceae, Artemisia, Chenopodiaceae and Salix and Betula nana shrubs; many places were altogether bare.

At $15.5 \mathrm{ka}$ cal. BP in PAZ 1a $\left(12,900{ }^{14} \mathrm{C} \mathrm{BP}\right)$ herbaceous plant communities and dwarf scrubs developed as a result of a slight temperature rise, palynologically characterised by higher values of Artemisia (Van der Hammen, 1951). Important heliophilous herbaceous taxa encountered in the pollen records of this period are Helianthemum, Rumex acetosa-acetosella, Polemonium, Thalictrum, Artemisia, Plantago major-media and Chenopodiaceae.

During the succeeding sub-zone $1 \mathrm{~b}$ from 14.8-14.1 ka cal. BP $\left(12,450-12,100{ }^{14} \mathrm{C}\right.$ BP $)$, especially Betula expanded. PAZ $1 \mathrm{~b}$ can be considered equivalent to the Bølling biozone and represents the vegetational changes as a result of the major climate change corresponding to GI-1e (Hoek, 2001).

The vegetation succession continued with $\mathrm{PAZ}$ 1c from $14.1-14.0 \mathrm{ka}$ cal. BP $\left(12,100-11,900{ }^{14} \mathrm{C} \mathrm{BP}\right)$, 
with a more open vegetation type, characterised by higher values of Non Arboreal Pollen (NAP) and Sal$i x$ and funiperus pollen percentages. PAZ $1 \mathrm{c}$ can be considered equivalent to the Older Dryas and correlates to GI-1d (Hoek, 2001).

During the Allerød, starting at $14.0 \mathrm{ka}$ cal. BP $\left(11,900{ }^{14} \mathrm{C} \mathrm{BP}\right)$, rather open Betula and later on $\mathrm{Pi}$ nus forests occurred. A sub-division can be made between a Betula phase (PAZ 2a) lasting from 14.0 to 13.2 ka cal. BP (11,900-11,250 $\left.{ }^{14} \mathrm{C} \mathrm{BP}\right)$ and Pinus phase (PAZ 2b) lasting from 13.2 to $13.0 \mathrm{ka}$ cal. BP $\left(11,250-10,950{ }^{14} \mathrm{C} \mathrm{BP}\right)$. At the end of the Allerød the pine forests were not in equilibrium with the then existing wetter climate conditions and for a large part died back (Bohncke, 1993). The many dead pine trees became prone to forest fires and burnt down which caused the Usselo soil of Allerød age frequently to contain charcoal particles. The weighted mean average of 23 charcoal radiocarbon dates presented in Hoek (1997c) yields $10,988 \pm 26{ }^{14} \mathrm{C} \mathrm{BP}$, which is coinciding with the end of PAZ $2 \mathrm{~b}$ or beginning of PAZ 3. Zone 2 as a whole can be considered equivalent to GI-1c to GI-1a.

The development to a more dense vegetation cover was interrupted with the start of the Younger Dryas (GS-1) at $13.0 \mathrm{ka}$ cal. BP $\left(10,950{ }^{14} \mathrm{C}\right.$ BP). During PAZ 3, the Pinus and Betula woods diminished in size and herbaceous plant communities developed. Heliophilous herbs became relatively more frequent indicating an opening up of the preceding boreal forest. This zone can be sub-divided into PAZ 3a from 13.0 to $12.7 \mathrm{ka}$ cal. BP $\left(10,950-10,550{ }^{14} \mathrm{C} \mathrm{BP}\right)$ and PAZ $3 \mathrm{~b}$ lasting from 12.7 to $11.8 \mathrm{ka}$ cal. $\mathrm{BP}$ (10,550$10,150{ }^{14} \mathrm{C}$ BP) during which Ericales, mainly Empetrum nigrum developed especially in the northern part of the Netherlands.

At the beginning of the Holocene, round $11.8 \mathrm{ka}$ cal. BP $\left(10,150{ }^{14} \mathrm{C} \mathrm{BP}\right)$, Betula forests expanded again. The vegetation development was not unidirectional. Localities where the early Holocene is present quite often register, after an initial spread of the tree birch (PAZ 4a), a short lasting interval during which a decline in the tree birch occurs and a spread in the grasses takes place (PAZ 4b). Van Geel et al. (1981) dated the Friesland-phase (PAZ 4a) between 11.8 $11.3 \mathrm{ka}$ cal. BP $\left(10,150-9,850{ }^{14} \mathrm{C} \mathrm{BP}\right)$, while the Rammelbeek phase (PAZ $4 \mathrm{~b}$ ) during which grasses prevailed was dated between 11.3 and $11.2 \mathrm{ka}$ cal. BP $\left(9,850-9,750{ }^{14} \mathrm{C} \mathrm{BP}\right)$.

The successive period of the early Holocene, during which both Betula pubescens and Betula pendula spread (PAZ 4c) followed by a Pinus increase (PAZ 5) round $10.7 \mathrm{ka}$ cal. $\mathrm{BP}\left(9,500{ }^{14} \mathrm{C} \mathrm{BP}\right)$ is called the Late Preboreal (11.2 - $10.2 \mathrm{ka}$ cal. BP). Remarkable is the role of Populus tremula during the onset of the Late Preboreal period. The appearance of the light requiring Populus underlines the openness of the vegetation at this stage in the vegetation development.

\section{Lithology of Lateglacial deposits}

The analysis of numerous Lateglacial deposits shows that a sub-division into different litho-facies can be made. Van der Hammen (1949) investigated these changes in organic content of lake sediments of Hijkermeer when he for the first time described the classical Lateglacial sub-division in The Netherlands (Fig. 2). In the coversand area, Van der Hammen \& Wijmstra (1971) recognised the same sub-division of the Lateglacial in the aeolian environment (Fig. 3). It can be concluded that changes in lithology during the Lateglacial, which have been recorded in different studies are closely related to changes in geomorphological processes.

During the Upper Pleniglacial, deflation processes had truncated the old surface level and its periglacial structures and left behind a desert pavement, a thin pebble layer called the Beuningen gravel bed, which is a recurrent level in many exposures with deposits from Pleni-and Lateglacial age. A radiocarbon date for this Beuningen gravel bed, which is often a complex of gravel layers is, in the absence of datable material, not possible, but it was generally assumed that it should be placed somewhere between 25 and $16.8 \mathrm{ka}$ cal. BP (Kolstrup, 1980). Subsequently, deposition of coversands prevailed (Older Coversand II, Fig. 3). This unit is deposited as sand sheets, horizontallybedded and laminated by alternating sand and loamy sand layers (Kasse, 1997). The conditions for preservation of organic material were poor, which resulted in a lack of radiocarbon dates from this period. Lithostratigraphically the Older Coversand II continues into the Lateglacial and correlates at least in part with the relatively warm and tree-less pre-Bølling sensu stricto or Earliest Dryas period (Kasse, 1999). Recent luminescence dating of these Older Coversands II by Bateman \& Van Huissteden (1999) yielded OSL age estimates between 17.5 and $13.9 \mathrm{ka} \mathrm{cal}$. BP. Deposition of aeolian sands mainly occurred during phases with a sparse vegetation cover. During the relatively stable Allerød, soil profiles developed that in some cases have been preserved in the lithological sequence. This palaeosol is referred to as the 'Usselo' soil after its type locality in Usselo (Van der Hammen, 1951) and is positioned between the Younger Coversands I and II (see Fig. 3).

The start of continuous Lateglacial organic accumulation at favourable localities in The Netherlands 
can be set at $12,450{ }^{14} \mathrm{C}$ BP or $14.8 \mathrm{ka} \mathrm{cal}$. BP (Hoek, 1997a). However, organic accumulations restricted to thin layers of humus or organic debris in predominantly minerogenic substrates occurred locally from $15.5 \mathrm{ka}$ cal. BP $\left(12,900{ }^{14} \mathrm{C} \mathrm{BP}\right.$ ) (Van Geel et al., 1989). Lateglacial peats consist predominantly of sedges or mosses, whereas wood or reed peat is scarce, although Phragmites was present during the Allerød at Usselo (Van Geel et al., 1989).

In lake deposits, a clear distinction can be made between different phases of the Lateglacial. Formation of lake marls or calcareous gyttja deposits is restricted to warmer parts of the investigated period. From the beginning of the Bølling period (GI-1e) at $14.8 \mathrm{ka}$ cal. BP to the end of the Allerød (GI-1a) at $13.0 \mathrm{ka}$ cal. BP and during the Early Holocene from $11.8 \mathrm{ka}$ cal BP onward, calcareous gyttjas could be deposited. During the Lateglacial, periods of calcareous gyttja formation often coincide with periods of peat formation, but in general peat is more common than calcareous gyttja.

The onset of the Younger Dryas (GI-1) is often characterised by an abrupt change in lithology. A sudden change from peat or calcareous gyttia to organic gyttja enriched in siliciclastic material has been recorded frequently. In the fluvial environment, a change from organic peat or gyttja to clay or silt marks the beginning of this period (Bohncke et al., 1993).

Another lithological change to more organic deposits has been recorded in many instances for the transition from the Younger Dryas to the Holocene in The Netherlands (Hoek, 1997a), which is comparable to the situation in e.g. Sweden (Björck et al., 1996).

\section{Geomorphology}

Geomorphological changes as a result of climatic change in the Lateglacial were relatively fast. The periglacial geomorphological processes that were active at the end of the Pleniglacial disappeared due to the changes in climate during the Lateglacial. Periglacial geomorphological processes during the Weichselian Lateglacial were closely related to the distribution of permafrost. The occurrence of continuous, discontinuous or sporadic permafrost is related to Mean Annual Air Temperature (MAAT). A value of $1^{\circ} \mathrm{C}$ is given as maximum threshold value for permafrost occurrence (Huijzer \& Isarin, 1997).

Not only the changes in climate, but also a developing vegetation cover formed an important cause for the changes in geomorphological processes during the Lateglacial. Erodibility of the substratum in par- ticular determines the intensity of geomorphological processes. The more dense a vegetation cover, the more resistant is the substratum against erosion. Therefore, the increasing vegetation cover since the beginning of the Lateglacial is supposed to have diminished the intensity of geomorphological processes. As a result of an increased vegetation cover, soil formation stabilised the substratum.

\section{Occurrence of permafrost}

Permafrost related phenomena, of which the indicators were frequently preserved in Pleniglacial sediments, must have been scarce during the Lateglacial, as only in some special cases permafrost structures became fossilised in Lateglacial sediments. According to De Groot et al. (1987), the expression of seasonal climatic variation during the Lateglacial was predominantly influenced by local abiotic factors such as lithology, hydrology and morphology. These factors determined the formation, evolution and preservation of the frost related phenomena. However, the occurrence of permafrost related phenomena, in combination with radiocarbon dates of these phenomena, indicate that permafrost was present during the Early Lateglacial and Younger Dryas stadial in The Netherlands.

Although it is often assumed that permafrost had disappeared directly after the formation of the Beuningen gravel bed, evidence from ice-cored terrains and from the infilling of pingo remnants demonstrate that relic ground ice was only starting to disappear shortly after $14.8 \mathrm{ka}$ cal. BP (e.g. Kasse \& Bohncke, 1992). This correlates well with the drastic temperature rise as recorded in the Greenland icecores at the start of GI-1e (Björck et al., 1998). Stable isotopes proved not only to be a temperature proxy $\left(\delta^{18} \mathrm{O}\right)$ but can also be used to reconstruct episodes of increased groundwater input $\left(\delta^{13} \mathrm{C}\right)$ as a result of final permafrost disappearance (Hoek et al., 1999).

The release of water from segregation ice and relic permafrost early in the Allerød (GI-1c), in combination with an increase in effective precipitation induced the spread of wet localities and the spread of a more continuous vegetation cover. Simultaneously the substratum became fixed and aeolian activity decreased (see Fig. 5).

In The Netherlands conditions approached those of permafrost environments again during the Younger Dryas. Many fossil periglacial structures assigned to the beginning of this episode confirm the extremity of the climate (Isarin, 1997). At Bosscherheide, periglacial loading structures have been described by Bohncke et al. (1993). The dark, highly organic 
Allerød soil, originally formed in a more or less horizontal position, and the underlying fluvial sands and loams have been deformed as a result of periglacial loading early in the Younger Dryas.

\section{Aeolian activity}

The formation of different forms of aeolian phenomena is closely related to the presence or absence of a vegetation cover and humidity of the substratum. From studies in actual periglacial environments we know that aeolian erosional phenomena such as desert pavements and deflation hollows can be formed simultaneously with depositional features such as coversand sheets and dunes, though at different places (Dijkmans \& Törnqvist, 1991). The deposition of coversands mainly took place during periods with sparse vegetation cover and bare surfaces. A source area with loose, available sand grains which can be transported by wind is essential for the initiation of aeolian processes on the one hand while on the other hand the presence of a vegetation cover favours the formation of dunes by interception of sand grains. Aeolian activity tends to occur regionally during specific time-intervals, arguing for a climatic control. From the coversand region the aeolian activity during the period under investigation is summarised and presented in Fig. 3 as a schematical cross-section along the Dinkel river in Twente, eastern Netherlands (modified after Wijmstra \& SchreveBrinkman, 1971). In later studies by Van Huissteden (1990) and Kasse (1999) other names are defined for the lithostatigraphic units or aeolian phases during the Late Pleniglacial and Lateglacial, however, these studies do not change the ideas on when aeolian activity occurred. Fig. 5 shows the principal phases of aeolian activity during the investigated period plotted against the INTCAL 98 calibrated ${ }^{14} \mathrm{C}$ time-scale.

Prior to GI-1 deposition of coversands prevailed (Older Coversand II). This unit is deposited as sand sheets, horizontally-bedded and laminated by alternating sand and loamy sand layers.

During GI-1e the vegetation cover developed and the substratum became fixed, consequently aeolian activity decreased since $14.8 \mathrm{ka}$ cal. BP. In areas where organic deposits corresponding to the Bølling biozone are present, a distinction can be made between Older Coversands II and Younger Coversands I. An approximate date for the termination of the Older Coversand II centers round $14.3 \mathrm{ka}$ cal. BP (Van Geel et al., 1989). Hence, this provides a minimum age for the Beuningen Complex of about 14.8$14.3 \mathrm{ka}$ cal.BP, which is in good correspondence with the recent OSL dates by Bateman \& Van Huissteden
(1999). Between 14.1 and $14.0 \mathrm{ka}$ cal. BP (GI-1d) deposition of coversands increased again, the so called Younger Coversand I were deposited. River incision and dry soil conditions possibly triggered the formation of inland dunes and coversands.

Aeolian activity did not stop completely during GI1e (Kasse, 1999), which makes the distinction between Older Coversands II and Younger Coversands I disputable especially in areas where a separating peat or organic layer is absent. This argues for an approach where well dated aeolian phases are compared to other records (see Fig. 5) rather than simply correlating fixed lithostratigraphic units.

During GI-1c aeolian activity diminished again and stable soil conditions may be deduced for this episode. During this relatively stable episode soil profiles developed (Usselo soil) that in some cases have been preserved in the lithological sequence. Near the end of GI-1 (round 13,0 ka cal. BP) temperature decline would have promoted unstable soil conditions causing renewed aeolian activity locally and establishment of discontinuous permafrost.

During GS-1 aeolian activity increased again reaching its greatest activity between 12.7 and 11.8 ka cal. BP (later part of GS-1), possibly linked to the disappearance of the discontinuous permafrost. Periodically emerging riverbeds formed the source for the aeolian sediments that accumulated as large parabolic river dunes under predominantly SW prevailing winds. Bohncke et al. (1993) provided an explicit date of $10,500 \pm 60{ }^{14} \mathrm{C} \mathrm{BP}$ for the start of aeolian deposition in a moss-layer directly underlying river dune deposits in Bosscherheide (southern Netherlands). These aeolian sediments in lithostratigraphical terms belong to the Younger Coversands II. The transition to the Holocene with the formation of a closed vegetation cover caused large scale aeolian activity to cease. In sequence de Borchert (Van Geel et al., 1981) a date of $10,150{ }^{14} \mathrm{C} \mathrm{BP}(11.8 \mathrm{ka}$ cal. BP $)$ is given for this event. After this only sporadically aeolian activity took place until the large-scale human disturbances of the vegetation cover later in the Holocene.

\section{Fluvial activity}

Fluvial activity is closely related to both discharge and sediment load, and beside climate, the role of vegetation and permafrost with respect to these factors is important. Fig. 5 shows a schematic overview of the principal fluvial changes in pattern plotted against a calibrated ${ }^{14} \mathrm{C}$ time-scale based on long-term research of the River Meuse. In the Meuse river valley, a series of abandoned river channels is present which form an 
archive of fluvial change from the Late Pleniglacial to the Early Holocene (Kasse et al., 1995; Van den Berg, 1996; Huisink, 1997, Tebbens et al., 1999). By dating these abandoned river channels, the morphological changes of the river patterns can be considered chronologically and a comparison with the vegetation history can be made.

At the end of the Pleniglacial the rivers Rhine and Meuse (Maas) had a braided pattern in The Netherlands. When vegetation became denser and permafrost disappeared during the beginning of the Lateglacial, discharge and sediment load diminished. The rivers reacted to the decrease in discharge and sediment load by changing from a braided towards a meandering pattern during GI-1e. From 14.0 to 13.0 ka cal. BP a large-scale high-sinuosity meandering system existed. Early in the Younger Dryas (GS-1) a return to almost periglacial conditions and the disappearance of a large part of the boreal forest took place. Together with the large-scale availability of sediment due to unstable soil conditions the water surplus led to drastic changes in the fluvial regimes. Multi-channel braided river systems were re-established. A next, deep incision into the Younger Dryas braided river plain occurred at the beginning of the Holocene round $11.8 \mathrm{ka}$ cal. BP (Berendsen et al., 1995). The deep incision at the onset of the Holocene was a result of the strong increase of the vegetation cover and a subsequent diminished discharge and sediment load.

\section{The relationship between vegetation and the abiotic landscape}

Certainly, geomorphological processes were favoured by a sparse vegetation cover, which implies a close interrelationship between vegetation and geomorphological processes. The Usselo soil is a characteristic soil horizon of Allerød age that is frequently present particularly in the coversand regions (Van der Hammen \& Wijmstra, 1971). The presence of the Usselo soil indicates that the underlying sediments were protected from deflation during later stages, e.g. the Late Dryas stadial. This underlines that increasing soil cohesion as a result of a developing vegetation cover and processing soil-formation is a main factor for Lateglacial geomorphological changes.

\section{Vegetational and geomorphological records}

As described above, changes in the abiotic landscape are closely interrelated with changes in vegetation. The vegetation development initiated soil formation and stabilised the substratum. On the other hand the abiotic landscape affected the vegetation development, especially the vegetation patterns (Hoek, $1997 \mathrm{~b} ; 2000$ ). For the investigation of the direct interactions between vegetation and geomorphological processes, vegetational and geomorphological records need to be combined. Especially from aeolian and fluvial environments, both vegetational and geomorphological evidence is available for Lateglacial environmental changes (see above). From pingo remnants filled with lake deposits or peat, many pollen diagrams have been obtained. The vegetation surrounding the lakes is therefore well known. These deposits, formed directly after melting of the pingos at the end of the Pleniglacial, provide excellent records of Lateglacial and Early Holocene environmental history. Geomorphological processes in the surroundings were recorded in pingo-remnant fillings, for instance by the influx of aeolian sands in the combined palynological and lithological record of Uteringsveen (Cleveringa et al., 1977). Bohncke \& Wijmstra (1988) described indications for unstable soil conditions during the Early and Late Dryas based on chemical analyses from lake-deposits in the pingo remnant Mekelermeer. Information considering lake-level change and aeolian influx as a result of a diminished vegetation cover can in a direct way be compared with the regional vegetation.

\section{Vegetation density}

Combined vegetational and geomorphological investigations are largely lacking. The comparison of vegetation patterns to the abiotic landscape surrounding the basin can give information about their relationship. Important for the geomorphological processes is the density of the vegetation cover. The arboreal pollen percentages (AP) are a measure for the forest density. An absolute value for the forest density based on AP percentages is difficult to establish, though relative changes in AP percentage may indicate absolute changes in forest density. Arboreal pollen percentages above $50 \%$ approximately indicate the presence of forest (Zagwijn, 1989). Within the arboreal pollen (AP), the main taxa are Betula and Pinus, to a lesser extent also Salix and Populus contribute to the AP percentage. In general it can be stated that higher values occurred during warmer periods. Lower AP percentages are indicative for herbaceous, more open vegetation types of colder intervals (Hoek, 2000). AP percentages in the river region were generally lower than in other parts of The Netherlands. Presumably, forests could not develop in the river plain during the period under investigation as a result of the dynamic fluvial environment. 
Hoek (1997c) has shown that in The Netherlands the vegetation cover was less dense during periods of change in the palynological record, which are dated to around 14.1, 13.5, 13.0 and around $11.3 \mathrm{ka}$ cal. BP. During these periods an aeolian influx in organic deposits has been recorded frequently, indicating that the vegetation was indeed sparser. In Fig. 5, a reconstruction of the forest density is given as a curve of the AP (arboreal pollen) and NAP (non arboreal pollen) plotted against the INTCAL98 calibrated ${ }^{14} \mathrm{C}$ time scale.

\section{Indicator taxa}

The rise of the Empetrum curve in Lateglacial pollen diagrams in The Netherlands, can generally be dated around $10,550{ }^{14} \mathrm{C}$ BP (12.7 ka cal. BP). It coincides in time with the formation of river dunes and coversand ridges during the Younger Dryas (GS-1). Empetrum nigrum is a species that is able to grow under active aeolian deposition, and therefore a possible indicator for the presence of aeolian activity. Other indicators for unstable soil conditions in aeolian environments are Artemisia, Plantago and Rumex. In fluvial environments, Chenopodiaceae and Cruciferae and moist species within the Galium-type are indicative for the occurrence of freshly deposited sediments (Hoek, 1997b).

The aeolian activity during the Younger Dryas caused damming of brook valleys by coversand ridges. As a result, wet basins could develop behind those ridges, which favoured the occurrence of for instance Salix. The replacement of Gramineae by Cyperaceae is also indicative for the occurrence of wetter environments (Hoek, 1997b).

\section{Combining the evidence}

Comparison of the different proxies on a common time-scale (Fig. 5) shows clear interrelationships between these proxies. Climate functions as a leading factor for both vegetational changes and geomorphological processes. A clear relationship can be recognised between the major climatic, vegetational and geomorphological events. Some relationships are less obvious but can be deducted from the combination of evidence; e.g. the drought during GI-1d as recorded by low lake-levels and aeolian activity might be a delayed response to the warming during GI-1e and subsequent final disappearance of relic permafrost during GI-1d.

Important to realise is that not the changes in climate directly, but the associated developing vegetation cover formed one of the major causes for the changes in geomorphological processes during the Lateglacial. Especially erodibility of the substratum determines the intensity of geomorphological processes. Increasing cohesion by a developing vegetation cover and soil-formation is the main factor in Lateglacial geomorphological changes. This can be seen in Fig. 5 where the phases of aeolian activity are linked to particularly the phases of a more open vege-

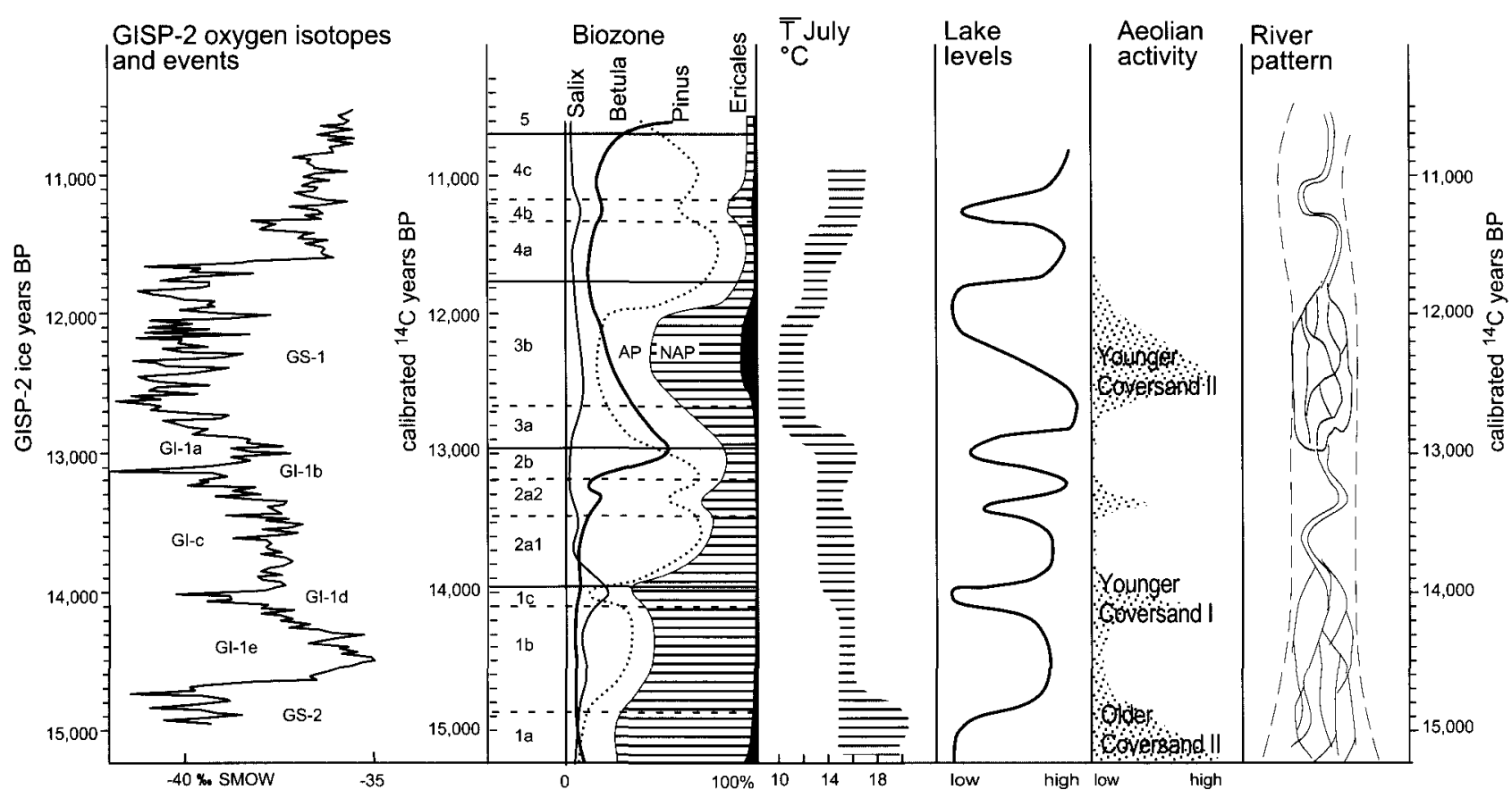

Fig. 5. Schematic overview of Lateglacial climatological, vegetational and geomorphological events plotted against a calibrated $14 \mathrm{C}$ timescale. GISP-2 oxygen isotope curve after Stuiver et al. (1995), river pattern after Huisink (1999). 
tation type. Not all phases of low lake-levels, associated with decreased wetness, can be correlated to increased aeolian activity (e.g. round 13.0 and $11.2 \mathrm{ka}$ ). These lower lake-levels occur during phases of a relative dense vegetation cover where apparently the threshold for increased aeolian activity was not passed.

Another important factor is the presence and disappearance of permafrost during the Lateglacial. During the Late Pleniglacial the rivers had a braided character as a result of large variations in discharge and sediment load. The vegetation development shows an important increase in the vegetation cover at the beginning of the Allerød-interstadial just after $14.0 \mathrm{ka}$ cal. BP. Changes in river pattern also took place at that time. This means that both vegetation and fluvial activity were not responding instantaneously to the climatic warming that started at ca $14.7 \mathrm{ka}$ cal. BP. This climatic warming, however, will have played an important role in the melting of the permafrost. When relic permafrost had completely disappeared round $14.0 \mathrm{ka}$ cal. BP, vegetation and rivers reacted almost simultaneously.

The complex interrelationships and feedback mechanisms can be illustrated by an example from the fluvial environment. Fluvial response to the climatic events during the Lateglacial is highly influenced by changes in vegetation density. The increased vegetation density diminished discharge and sediment load, which subsequently caused concentration and incision of the rivers. On the other hand, river incision and the formation of meandering systems, that happened to take place at the end of the Bølling (GI1e), might well have caused a temporary decline in the ground water level in areas adjacent to rivers (Bohncke et al., 1993; Kasse et al., 1995). The same mechanism can explain the drier conditions during the Early Holocene Rammelbeek phase. The lowering of the ground water levels will certainly have influenced the local vegetation composition at these periods, which indeed indicates drier conditions.

This paper shows that the combination of different lines of evidence and the recognition of events in different environments might help us to understand the complex interrelationships between climate and the landscape during a period of rapid change such as the Weichselian Lateglacial.

\section{Acknowledgments}

This paper is a contribution to the INTIMATE project of the INQUA Palaeoclimate Commission [http://www.geog.uu.nl/fg/INTIMATE/]. Dr. W. de Gans, Dr. R.T. van Balen and Dr C. Kasse are ac- knowledged for their valuable comments on this paper. Prof. Dr W.H. Zagwijn is acknowledged for his advice and comments on an earlier draft of this paper and Dr. G. Aalbersberg for his help making the Figs.

\section{References}

Atkinson, T.C., Briffa, K.R. \& Coope, G.R., 1987. Seasonal temperatures in Britain during the past 22,000 years, reconstructed using beetle remains. Nature 325: 587-593.

Bateman, M.D. \& Van Huissteden, J., 1999. The timing of lastglacial periglacial and aeolian events, Twente, eastern Netherlands. Journal of Quaternary Science 14: 277-283.

Berendsen, H., Hoek, W. \& Schorn, E., 1995. Late Weichselian and Holocene river channel changes of the rivers Rhine and Meuse in the Netherlands (Land van Maas en Waal). Paläoklimaforschung/Palaeoclimate Research 14: 151-171.

Björck, S., Kromer, B., Johnsen, S., Bennike, O., Hammarlund, D., Lemdahl, G., Possnert, G., Rasmussen, T.-L., Wohlfarth, B., Hammer, C.-U. \& Spurk, M., 1996. Synchronized TerrestrialAtmospheric Deglacial Records Around the North Atlantic. Science 274: 1155-1160.

Björk, S., Walker, M.J.C., Cwynar, L.C., Johnsen, S., Knudsen, K.L., Lowe, J.J., Wohlfarth, B. \& INTIMATE Members 1998. An event stratigraphy for the Last Termination in the North Atlantic region based on the Greenland ice-core record: a proposal by the INTIMATE group. Journal of Quaternary Science 13: 283-292.

Bohncke, S.J.P., 1993. Lateglacial environmental changes in The Netherlands: spatial and temporal patterns. Quaternary Science Reviews 12: 707-718.

Bohncke, S.J.P. \& Vandenberghe, J.F., 1991. Palaeohydrological development in the Southern Netherlands during the last 15,000 years. In: Starkel, L., K.J. Gregory \& J.B. Thornes (eds.), Temperate Palaeohydrology. Wiley \& Sons, Chichester, pp. 253-281.

Bohncke, S.J.P., Vandenberghe, J.F., Coope, G.R. \& Reiling, R., 1987. Geomorphology and palaeoecology of the Mark valley (southern Netherlands): palaeoecology, palaeohydrology and climate during the Weichselian Lateglacial. Boreas 16: 69-85.

Bohncke, S.J.P., Wijmstra, T.A., Van der Woude, J. \& Sohl, H., 1988. The Late-Glacial infill of three lake successions in The Netherlands: Regional vegetational history in relation to NW European vegetational developments. Boreas 17: 385-402.

Bohncke, S.J.P. \& Wijmstra, T.A., 1988. Reconstruction of LateGlacial Lake-level fluctuations in The Netherlands based on palaeobotanical analyses, geochemical results and pollen-density data. Boreas 17: 403-425.

Bohncke, S.J.P., Vandenberghe, J.F. \& Huijzer, A.S., 1993. Periglacial palaeoenvironment during the Lateglacial in the Maas valley. Geologie en Mijnbouw 72: 193-210.

Bohncke, S.J.P. \& Hoek, W.Z. (in press) Weichselian Lateglacial environmental and climate changes in the Netherlands. Encyclopedia of Quaternary Science, Chapman and Hall.

Cleveringa, P., De Gans, W., Kolstrup, E. \& Paris, F.P., 1977. Vegetational and Climatic developments during the Late Glacial and the Early Holocene and Acolian sedimantation as recorded in the Uteringsveen (Drente, The Netherlands). Geologie en Mijnbouw 56: 234-242.

Coope, G.R., Lemdahl, G., Lowe, J.J. \& Walkling, A., 1998. Temperature gradients in northern Europe during the Last GlacialHolocene transition (14-9 ${ }^{14} \mathrm{C}$ kyr BP) interpreted from coleopteran assemblages. Journal of Quaternary Science 13: 419-433.

De Groot, T.A.M., Cleveringa, P. \& Klijnstra, B., 1987. Frost- 
mound scars and the evolution of a Late Dryas environment (northern Netherlands). Geologie en Mijnbouw 66: 239-250.

Dijkmans, J.W.A. \& Törnqvist, T.E., 1991. Modern periglacial aeolian deposits and landforms in the Søndre Strømfjord area, West Greenland and their palaeoenvironmental implications. Meddelser om Grønland, Geoscience 25: 1-39.

Florschütz, F., 1939. Die paläobotanische Grenze PleistozänHolozän in den Niederlanden. Recueil des Travaux Botaniques Néerlandais 36: 550-558.

Grootes, P.M., Stuiver, M., White, J.W.C., Johnsen, S. \& Jouzel, J., 1993. Comparison of oxygen isotope records from the GISP2 and GRIP Greenland ice cores. Nature 366: 552-554.

Hoek, W.Z., 1997a. Palaeogeography of Lateglacial Vegetations Aspects of Lateglacial and Early Holocene vegetation, abiotic landscape, and climate in The Netherlands. Netherlands Geographical Studies 230, Utrecht/Amsterdam, $160 \mathrm{pp}$.

Hoek, W.Z., 1997b. Atlas to Palaeogeography of Lateglacial Vegetations - Maps of Lateglacial and Early Holocene landscape and vegetation in The Netherlands, with an extensive review of available palynological data. Netherlands Geographical Studies 231, Utrecht/Amsterdam, $176 \mathrm{pp}$.

Hoek, W.Z., 1997c. Late-Glacial and early Holocene climatic events and chronology of vegetation development in the Netherlands. Vegetation History and Archaeobotany 6: 197-213.

Hoek, W.Z., 2000. Abiotic landscape and vegetation patterns in the Netherlands during the Weichselian Late Glacial. Geologie en Mijnbouw/Netherlands Journal of Geosciences 79:497-509.

Hoek, W.Z., 2001. Vegetation response to the 14.7 and 11.5 ka yrs BP climate transitions: is vegetation lagging climate? Global and Planetary Change 30: 103-115.

Hoek, W.Z., Bohncke, S.J.P., Ganssen, G.M. \& Meijer, T., 1999. Lateglacial environmental changes recorded in calcareous gyttja deposits at Gulickshof, southern Netherlands. Boreas 28: 416432 .

Hoek, W.Z. \& Bohncke, S.J.P., 2001. Oxygen-isotope wigglematching as a tool for synchronising ice-core and terrestrial records over Termination 1. Quaternary Science Reviews 20: 1251-1264.

Huisink, M., 1997. Sedimentological and morphological changes of a lowland river as a response to climatic change; the Maas, The Netherlands. Journal of Quaternary Science 12: 209-223.

Huisink, M., 1999. Changing river styles in response to climate change. Examples from the Maas and Vecht during the Weichselian Pleni- and Lateglacial. PhD-thesis Vrije Universiteit Amsterdam, $127 \mathrm{pp}$.

Huijzer A.S. \& Isarin, R.F.B., 1997. The reconstruction of past climates using multi-proxy evidence; an example of the Weichselian Pleniglacial in northwest and central Europe. Quaternary Science Reviews 16:513-533.

Isarin, R.F.B., 1997. Permafrost distribution and temperatures in Europe during the Younger Dryas. Permafrost and Periglacial Processes 8: 313-333.

Isarin, R.F.B., Renssen, H. \& Vandenberghe, J., 1998. The impact of the North Atlantic Ocean on the Younger Dryas climate in north-western and central Europe. Journal of Quaternary Science 13: 447-453

Isarin, R.F.B. \& Bohncke, S.J.P., 1999. Mean July temperatures during the Younger Dryas in northwestern an central Europe as inferred from climate indicator plant species. Quaternary Research 51: 158-173.

Iversen, J., 1947. Plantevaekst, Dyreliv og Klima i det senglaciale Danmark. Geologiske föreninger i Stockholm förhandlingar 69 : 67-78.

Iversen, J., 1954. The Late-Glacial Flora of Denmark and its Relation to Climate and Soil. In: Studies in Vegetational History,
Danmarks Geologiske Undersogelske 2(80): 88-119.

Iversen, J., 1973. The Development of Denmark's Nature since the Last Glacial. Danmarks Geologiske Undersøgelse 5(7C): 1-126.

Johnsen, S.J., Clausen, H.B., Dansgaard, W., Fuhrer, K., Gundestrup, N., Hammer, C.U., Iversen, P., Jouzel, J., Stauffer, B. \& Steffensen, J.-P., 1992. Irregular glacial interstadials recorded in a new Greenland ice core. Nature 359: 311-313.

Kasse, C., 1997. Cold-climate aeolian sand-sheet formation in North-Western Europe (c. 14-12.4 ka); a response to permafrost degradation and increased aridity. Permafrost and Periglacial Processes 8: 295-311.

Kasse, C., 1999. Late Pleniglacial and Late Glacial aeolian phases in The Netherlands. In: W. Schirmer (ed.) Dunes and fossil soils. GeoArchaeoRhein 3: 61-82.

Kasse, K. \& Bohncke, S., 1992. Weichselian Upper Pleniglacial aeolian and ice-cored morphology in the Southern Netherlands (Noord-Brabant, Groote Peel). Permafrost and Periglacial Processes 3: 327-342.

Kasse, K., Vandenberghe, J. \& Bohncke, S., 1995. Climatic change and fluvial dynamics of the Maas during the Late Weichselian and Early Holocene. Paläoklimaforschung/Palaeoclimate Research 14: 123-150.

Kolstrup, E., 1980. Climate and stratigraphy in Northwestern Europe between $30,000 \mathrm{BP}$ and $13,000 \mathrm{BP}$, with special reference to The Netherlands. Mededelingen Rijks Geologische Dienst 32: 181-253.

Lowe, J.J., Hoek, W.Z. \& INTIMATE group, 2001. Inter-regional correlation of palaeoclimatic records for the Last Glacial-Interglacial Transition: a protocol for improved precision recommended by the INTIMATE project group. Quaternary Science Reviews 20: 1175-1187.

Mangerud, J., Andersen, S.T., Berglund, B.E. \& Donner, J.J., 1974. Quaternary stratigraphy of Norden, a proposal for terminology and classification. Boreas 3: 109-128.

Renssen, H. \& Isarin, R.F.B., 2001. The two major warming phases of the last deglaciation at $\sim 14.7$ and $\sim 11.5 \mathrm{kyr}$ cal BP in Europe: climate reconstructions and AGCM experiments. Global and Planetary Change 30: 117-153.

Renssen, H., Isarin, R.F.B., Vandenberghe, J. \& workshop participants, 2001. Research prospects for palaeoclimatic reconstructions of the last glacial-interglacial cycle with emphasis on abrupt warming. Global and Planetary Change 30: 155-165.

Stuiver, M., Grootes, P.M. \& Braziunas, T.F., 1995. The GISP2 $-{ }^{18} \mathrm{O}$ Climate Record of the Past 16500 Years and the Role of the Sun, Ocean, and Volcanoes. Quaternary Research 44: 341-354.

Stuiver, M., Reimer, P.J., Bard, E., Beck, W., Burr, G.S., Hughen, K.A., Kromer, B., McCormac, G., Van der Plicht, J. \& Spurk, M. 1998. INTCAL98 radiocarbon age calibration $24,000-0$ cal BP. Radiocarbon 40: 1041-1083.

Tebbens, L.A., Veldkamp, A., Westerhoff, W. \& Kroonenberg, S.B. 1999. Fluvial incision and channel downcutting as a response to Late-glacial and Early Holocene climate change: the lower reach of the River Meuse (Maas), The Netherlands. Journal of Quaternary Science 14: 59-75.

Vandenberghe, J.F., 1992. Periglacial Phenomena and Pleistocene Environmental Conditions in the Netherlands - An Overview. Permafrost and Periglacial Processes 3: 363-374.

Vandenberghe, J.F., Bohncke, S.J.P., Lammers W. \& Zilverberg, L., 1987. Geomorphology and palaeoecology of the Mark valley (southern Netherlands): geomorphological valley development during the Weichselian and Holocene. Boreas 16: 55-67.

Van den Berg, M.W., 1996. Fluvial sequences of the Maas, a $10 \mathrm{Ma}$ record of neotectonics and climate change at various time-scales. PhD-thesis, Wageningen, $181 \mathrm{pp}$.

Van der Hammen, Th., 1949. De Allerød-oscillatie in Nederland, 
pollenanalytisch onderzoek van een laatglaciale meerafzetting in Drente, I \& II, Koninklijke Nederlandse Academie van Wetenschappen Proceedings 52: 69-75 and 169-176.

Van der Hammen, Th., 1951. Late-Glacial flora and periglacial phenomena in The Netherlands. PhD-thesis, Leiden, Leidse Geologische Mededelingen 17: 7i-183.

Van der Hammen, Th. \& Wijmstra, T.A. (eds.), 1971. The Upper Quaternary of the Dinkel valley, Mededelingen Rijks Geologische Dienst 22, 213 pp.

Van Geel, B., 1996. Factors influencing changing AP/NAP ratios in NW-Europe during the Late-Glacial period. Il Quaternario 9: 599-604.

Van Geel, B. \& Kolstrup, E., 1978. Tentative explanation of the Late Glacial and Early Holocene climatic changes in north-western Europe. Geologie en Mijnbouw 57: 87-89.

Van Geel, B., Bohncke, S.J.P. \& Dee, H., 1981. A Palaeoecological study of an upper Lateglacial and Holocene sequence from 'De Borchert', The Netherlands. Review of Palaeobotany and Palynology 31: 367-448.
Van Geel, B., Coope, G.R. \& Van der Hammen, Th., 1989. Palaeoecology and stratigraphy of the Lateglacial type section at Usselo (The Netherlands). Review of Palaeobotany and Palynology 39: 25-129.

Van Huissteden, J., 1990. Tundra rivers of the last glacial: sedimentation and geomorphological processes during the Middle Pleniglacial in Twente, Eastern Netherlands. Mededelingen Rijks Geologische Dienst 44: 1-138.

Wijmstra, T.A. \& Schreve-Brinkman, E.J., 1971. The Lutterzand section. In: Van der Hammen, Th. \& T.A. Wijmstra (eds.), 1971. The Upper Quaternary of the Dinkel valley, Mededelingen Rijks Geologische Dienst 22: 87-100.

Zagwijn, W.H., 1994. Reconstruction of climate change during the Holocene in western and central Europe based on pollen records of indicator species. Vegetation History and Archaeobotany 3: 65-88.

Zagwijn, W.H., 1989. Vegetation and climate during warmer intervals in the Late Pleistocene of western and central Europe. Quaternary International 3-4: 57-67. 